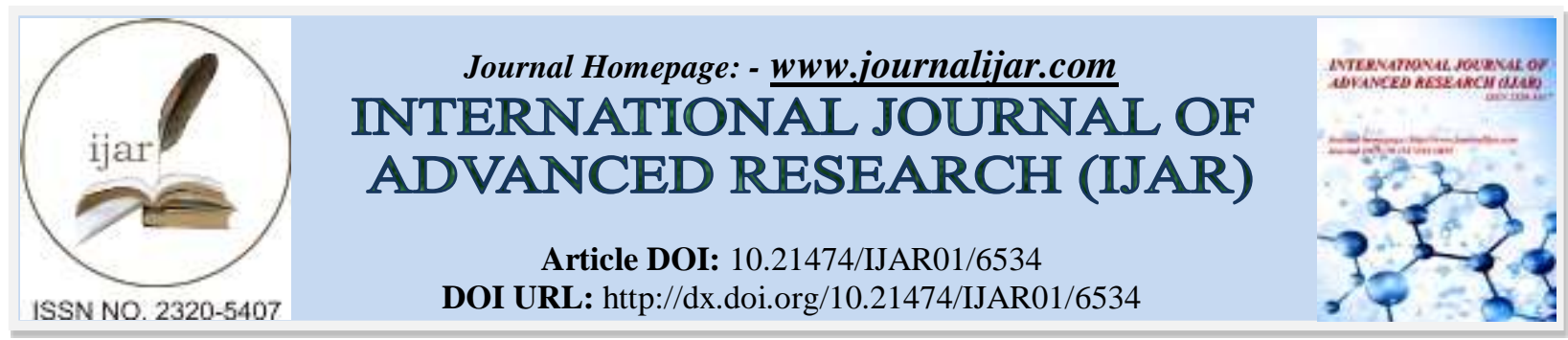

RESEARCH ARTICLE

\title{
PHOTOPERIODIC BIODIVERSITIES UNDER LIGHTPOLLUTION IN INDIA DURING ANTHROPOCENE EPOCH.
}

Siba Prasad Mishra.

Civil Engineering Department, Centurion University technology and management, Jatni, BBSR, Odisha.

\section{Manuscript Info}

Manuscript History

Received: 14 December 2017

Final Accepted: 16 January 2018

Published: February 2018

Key words:-

Anthropocene, Light pollution,

Illumination, Biodiversity, Artificial

lighting.

\section{Abstract}

Air, water and soil pollution have confirmed impact on Air, The air, water and soil pollution have confirmed impact on livings but the influence of light pollution on habitats comfort, nocturnal life forms and loss of panaroma of sky by city dwellers at the cost of diminishing energy resources is yet to be established. The light pollution due to artificial lights can upset both (vitro and vivo) of human, disrupt ecosystem, affect natural circadian cycles of habitats, disorder the reproductivity, photoperiodism and growth metabolism of plants and microorganisms. Proper illumination enhances visibility, productive hours and encourage safety. The light pollution (LP) is caused by excess artificial light of human activities in Anthropocene epoch. There is a long gap between the study of LP parameters and its effect. There is discoordination between its measurement, causes, effects and setting of ameliorative measures. The present work is the analysis of SQM results of NOAA VIIRS/DMSP world atlas map of LP from 1992. LP in India is continuously increasing in almost all the cities and the whole country. It is increasing @ 2.3\%/annum in India from 1992 whereas the radiance in Delhi, Calcutta, Chenei, Bengluru, Hyderabad Mumbai and Ahamadabad have increased @ 102\% during 2014 to 2017 considering 2013 is the base year. Radiance of the Chennai city was the highest followed by Mumbai and New Delhi. The artificial, the ratio of natural radiance to artificial radiance have also increased more in Hyderabad, Calcutta and New Delhi cities. The Bortle scaling of the major cities of India are mostly of class 8-9. Since LP is growing as a major problem in the Anthropocene epoch, it is high time to monitor the radiance, artificial pollution and impart appropriate steps to ameliorate the LP. The haze and the smog has become a part to the light pollution.

Copy Right, IJAR, 2018,. All rights reserved.

\section{Introduction:-}

Daily activities of all plants and animals have diurnal by evolution. They are agile during day and tranquil at night. Light and radiation plays vital role in the life process. Presently the night is artificially engineered to have equal radiance as day. Like air, water, noise, $\mathrm{CO}_{2}$ and soil pollution, the globe is marching in the way of light pollution. Light pollution (LP) is like air, water, noise and soil pollution which affect the growth and death of livings. It is the artificial outdoor lighting which is excessive, invasive, misused and misdirected . In the mid $20^{\text {th }}$ century, the starry sky at night was spectacular. But in early $21^{\text {st }}$ century we, the urban dwellers do rarely get a chance of seeing the 
Milky Way or the stars Dhruba or the Saptarsi Mandal in Cities. The augmented and extensive use of artificial light at night is depriving us to the noctural panaromic views of our universe.

It is well accepted that the geological age the Holecene Epoch (11700 years old) has been succeded by Anthropocene Epoch since the first day of nuclear test in 1945 Mishra S. P., $(2017)^{[1]}$ though it is not officially acknowledged till date. It is contentious about the official age of acceptance considering its geochronology and startigraphy though the Anthropocene working group is working on war footing basis on it. Like other pollutions, the light pollution has become a part of the the new epoch which has distorted the life style and the biological clock of human being. N. Rathnasree, Director Neheru Planetorium, New Delhi, researching on levels of light pollution in India, says "Air and water pollution have prompt impact on health". Strong penetrative light invites burning of the retina but artificial light causes light pollution (LP) that is affecting nocturnal life of all species. Meteropolies are vulnerable to light pollution and citizens are more sensitised than other species.



\section{What is light:-}

Source: https://mpetroff.net/2016/06/light-pollution-

Light is the electromagnetic radiation consisting of a stream of photons,source being the sun. The visible range of spectrum for human is 380 to $700 \mathrm{~nm}$. The sun emits radiation of all spectrum of wavelengths where ultraviolet (UV) and Infra Red (IR) lights are harmful. Largely the iono-sphere blocks 95-99.9\% of UV and infrared radiations of sun before reaching earth. The light in its electromagnetic energy form has radiation in both wave and particle character. The living eye absorb them by photoreceptor when it is in particle form. The entire spectrum of light has three band of wavelengths i.e. ultraviolet, visible light and infrared (100-400 nm), (400-760 nm) and (760$10000+\mathrm{nm}$ ) respectively. Further UV light has been divided into three subgroups such as UVA, UVB and UVC having wave length range $(315-400 \mathrm{~nm}),(280-315 \mathrm{~nm}),(100-280 \mathrm{~nm})$. Respectively https://safety.dept.shef.ac.uk /ir/uv safety.pdf. Similarly IR spectrum has been classified as IRA, IRB and IRC of (700-1400 nm), (1400$3000 \mathrm{~nm})$, (3000-10 000+ $\mathrm{nm})$ respectively. But visible light is can have three major colours as short (blue), medium (green) and long wavelengths (red). The cornea and the lense absorbs all radiations of range $<295 \mathrm{~nm}$ ( UVB and UVC). The strength of UV ray pollution deped upon the distance from source, time and length of exposure. But wave length received by the lenses above UVA, IRA, IRB and IRC ranges cause damage to retina by photothermal, Photomechanical or photochemical actions. The FIR (far infrared) radiation $(\lambda=3-100 \mu \mathrm{m})$, a subdivision of frequency spectrum $(400 \mathrm{THz}-3 \mathrm{THz})$, and photon energy range $(12.4 \mathrm{meV}-1.7 \mathrm{eV})$, the long wavelength at the edge of the visible red has good biologycal effects and health benefits Vatnsever et al (2013) ${ }^{[2]}$. It can also be classified as near-infrared (NIR) $(0.8$ to $8 \mu \mathrm{m})$, mid-infrared $(8.0$ to $30 \mu \mathrm{m})$ and far-infrared $(30$ to $300 \mu \mathrm{m})$ Lee et al., $(2006)^{[3]}$.

\section{Light pollution:-}

light pollution is the atmospheric discoloration of the night sky under influence of anthropogenic artificial light. Light pollution is any artificial light that includes wasteful, obtrusive, misdirected, inappropriate, invasive and redundant lights constituting photons and illuminants at night. Fighting LP never intend to turn off all lights at night. Sunpreet Singh August 12, 2016 in Newyork Times narated that exposure to long term light pollution causes, skin cancer, loss of vision, ostoporosis in bones and make the mussels week in human.Natural UV radiations augment risk of accidents, breast cancer, gastrointestinal, letahrgy and cardiovasular disorders and blue light hazard . But the 
UV generated due to short term exposure to artificial lightening on healthy people cinsidered insignificant. Since lack of long term data, response to long term exposure could not be evaluated but speculated as little risk of squamous cell carcinoma, eye and skin diseases as per Scientific Committee on Emerging and Newly Identified Health Risks (SCENIHR).Actinic UV affect eye and skin.

Nocturnal Lights can deteriorate smog situations for a city as was in Delhi 2017. The continuous Ozone cycle is given as: Nitrogen Dioxide (NO2) exhausted from automobiles undergoes photolysis by UV radiation (hv) received from solar radiations and decomposes into Nitrogen Oxide (NO) i.e. $\mathrm{NO} 2+\mathrm{h} v=>\mathrm{NO}+\mathrm{O}$ (as radical).... (i) $\mathrm{O} 2$ (air) $+\mathrm{O}$ (radical) $=>\mathrm{O} 3$ (Ozone) ... (ii) and $\mathrm{O} 3+\mathrm{NO}=>\mathrm{O} 2+\mathrm{NO} 2 \ldots$ (iii). Light synthesizes the nitrate ion $\left(\mathrm{NO}_{3}\right)$ whose concentration increases at night. In presence of VOC (Volatile organic compounds), the process of smog formation is accelerated. The sunlight synthesizes $\mathrm{NO}_{3}$ ion but the street lights are $\approx 25$ times sturdier than the full moon light. The collective effect lessens the $\mathrm{NO}_{3}$ 's levels by $7 \%$ which increases smog formation by $5 \%$ under light pollution. http://cescos.fau.edu/observatory/lightpol-environ.html

The artificial light sources: Artificial lights at out doors are mainly from street lights, lights in docks and airports . Europian commission, 2011 has classified high intensity outdoor lights such as sodium lamps of high and low pressure, mercury, metal halide, compact fluorescent (CFL), LED, incandescent/Halogen and fluorescent lamps according to their wave length, maximum efficiency and use is given in Table 1.

Table 1:- Wave length, maximum efficiency and uses of different high intensity lamps as source of artificial lighting (street lighting) as per Europian commission - 2011 and Claudia Rieswijk, 2014

\begin{tabular}{|c|c|c|c|c|c|}
\hline$\#$ & Typre of light & Materials & Wave length & Efficiency & Use \\
\hline 1 & $\begin{array}{ll}\text { High } & \text { intensity } \\
\text { lamps(HID) } & \\
\end{array}$ & & $\mathrm{nm}$ & $\begin{array}{l}\text { lumens/ } \\
\text { Watt }\end{array}$ & \\
\hline a. & High-pressure & sodium lamps & $\begin{array}{l}460-500,570- \\
600,745\end{array}$ & $50-130$ & $\begin{array}{l}25000 \mathrm{hr} / 6.25 \text { years,yellow colour, } \\
\text { lowarc voltage,bannedbut common }\end{array}$ \\
\hline & Low pressure (LPS) & Sodium lamps & 589 & $100-203$ & $\begin{array}{l}\text { monochromatic yellow color, most } \\
\text { common, late start }\end{array}$ \\
\hline b. & High pressure & Mercury lamps & $\begin{array}{l}184,253,365 \\
-435,546-578\end{array}$ & $35-60$ & $\begin{array}{l}\text { Banned but in use, } 4-7 \text { mnt warm- } \\
\text { up time, middling energy efficie } \\
\text { ncy (about } 50 \mathrm{~lm} / \mathrm{W} \text { ), less colour }\end{array}$ \\
\hline & Metal halide & (quartz) & $300-800$ & $75-140$ & $\begin{array}{l}\text { 18000hours } / 4.5 \text { years, light } \\
\text { pollution, }\end{array}$ \\
\hline 2 & Compact fluroscent & CFL lamps & $280-700$ & $50-85$ & Rare, road with less use \\
\hline 3 & Light emitting diods & LED lamps & $450-700$ & $\leq 50$ & $\begin{array}{l}\text { drawback of LED is greater upfront } \\
\text { cost and lower energy efficiency }\end{array}$ \\
\hline 4 & Incandescent/Halogen & $\begin{array}{l}\text { Tungsten/tungst } \\
\text { en halogen }\end{array}$ & $300-900$ & $5-27$ & $\begin{array}{l}\text { Banned, fragile and blue lights, } \\
\text { short life, vibration }\end{array}$ \\
\hline 5 & Fluroscent tubes & & $480-570$ & $60-105$ & $\begin{array}{l}\text { Rare in use, produce less light, } \\
\text { adversely affected by hot or cold } \\
\text { temperatures }\end{array}$ \\
\hline
\end{tabular}

Types of Light pollution:-

Light pollution as explained by NASA is over use or misuse of artificial light. LP also includes over illumination, glare, slughish light, clutter, light tresspass, smog and sky glow. These light effects are the common nocturnal bursts in Anthropocene epoch. Scattering of Artificial light on the octet of atmosphere raises night sky luminance,

Excess illumination - Excess lighting intensity of an area due to misuse of light, wastage of energy, enhancing utility costs, encouraging air pollution and disruption of natural sleep patterns of all livings

Glare - Visual discomfort or disability of vision in artificial bright light. Glare do not interfere vision but difficult to detect and place objects. The unit of glare is Unified Glare Rating (UGR) which should be low and limited to values 5 to 40 UGR for human vision. https://thegrid.rexel.com/en-us/lighting/w/wiki/266.Glare can be of four types such as blinding glare (temporary or permanent blindness), disability glare (automobile lights), 
discomfort glare (temporary annoying and irritating light), veiling glare (back ground flip-flop luminance). Discomfort glare can be further subdivided as saturation glare, contrast glare. Similarly disability glare can be subdivided as veiling brightness and successive glare.

Sky glow - Brightening of the night sky over an inhabited areas make the sky covered with light in cities and missing night sky full of twinkling stars and milk ways, are the examples of sky glow. Excess light from street lamps, parking places in outdoor go up and rebounds back down to the city from the atmosphere and affect natural growth of plants and night haunting animals. World Atlas of Artificial Night Sky Brightness had reported $80 \%$ of the world's population and $99 \%$ from U.S. and Europe can't experience a natural night! http://www.darksky.org/light-pollution/

Light trespass -Unwanted light falling in our property where it is not intended causes crimes or disturbing tranquility of an area. It is done either by flickered, UV or blue lights used for excess illumination above nadir. Luminaire optics, placement, light levels and timing are examples of light trespass. Such light causes sleeplessness, retinal damage, affects skin also.

Clutter-Anthropogenic bright, confusing and excessive groupings of light sources creates a contrast illumination and interference occurs in roads at night vision affecting nocturnal dwelling of habitats. Mostly open-air LASER shows, Light and sound programms fall in the category.

Haze and smog -Herald Stark, of the National Oceanic and Atmospheric Administration linked LP is caused by excess smog and ozone near cities. Smog invites haze, the mask covering the nadir. The hazy nights with LP are observed in many large cities like Delhi, Calcutta, Ahmadabad and Bengaluru in India.

\section{Review of literature:-}

Wäldchen S. et al, $(2015)^{[4]}$ have reported that photons with high intense irradiation, illumination, light-dose, wavelength, , temperature and fluorescence can cause cellular damage cells within 20-24hours exposure. Youssef P. $\mathrm{N}$. et al., $2010^{[5]}$ told that light has capability to cause damage in retina and appaurtinent organs due to thermal, mechanical, and chemical mechanisms of photons. Ron Chepesiuk, $(2009)^{[6]}$ have reported that about 5-50 million birds die annually due to collision with communication towers. Rohdents and carnivores, (marsupials, and nocturnal), the turtles and birds fall prey to night lighting in huge numbers. Cho $\mathrm{S}$ et al, (2009) ${ }^{[7]}$ told that IR and heat $\left(>40^{\circ} \mathrm{C}\right)$ contact encourages premature skin aging and skin damage due to hyperthermia .Salma R. B,. (2016) ${ }^{[8]}$ have pointed that the the far-infrared spectrum emitted by surfaces are arrested by the GHGs, cause globalwarming and hence the climate change. Falchi Fabio et al., (2016) ${ }^{[9]}$ had prepared artificial night sky brightness atlas of the world and they had shown, $83 \%$ of the population of the world and $>99 \%$ of the U.S. and European countries are living under LP skies. Zhang Q. et al., $2016^{[10]}$ found the RSR method to analyse the DMSP/OLS data which is less time consuming for analysis of big data from sattelite imageries and developed time series for radiance from 1992 to 2012. Gaston et al $(2013)^{[11]}$ have reported that there is positive impact of noctural artificial lighting of biological cell to ecosystem at all frequency levels. Claudia R., defined light pollution as "the degradation of the photic habitat by artificial light." George M. P. et al (2013) ${ }^{[12]}$, Delhi smog, was cause for pollutants like SPM (PM10 and PM2.5), $\mathrm{No}_{2}$, Ozone, $\mathrm{NH}_{3} \mathrm{SO}_{2}$ and $\mathrm{CO}$ along with anthropocene activities like Dewali polluted air which had invited haze and light pollution. Kyba et al., (2017) ${ }^{[13]}$ reported that artificial radiance outdoor area had grown by $2.2 \% /$ year, whereas total radiance growth was @ $1.8 \%$ annually considering data of 2012 to 2016 . Bortle J. E. (2006) ${ }^{[14]}$, reported that the naked-eye limiting magnitude (NELM) is a poor estimation of magnitudes of stars in an bare eye and classified the status of sky into a nine level scale Fig 2. BSI (British Standards Institute), (2003) ${ }^{[15]}$, Gaston et al., (2013) ${ }^{[64]}$ mentioned that the variation in levels of illumination (in Lux) for well lighted offices, homes, street lights, parking places, and urban sky glow are approximately (400-600), (100 -300), 15, 10, 5 and 0.15 Lux respectively where as this radiance is varying since last decade. Hunter P. (2007) ${ }^{[17]}$ told that urbanization shares evolution and adaptive courses to examine the Anthropogenic effect of humans on flora,fauna, avifauna and aqua fauna. creates the potential to mitigate any negative effects. Lamphar H. A. S, $(2013)^{[18]}$ found that the effects light pollution can be reduced with simultaneous proper selection of the type of the lamp and its scotopic luxes at the ground which can ameliorate the ill effects of sky glow. Bhandari et al., (2011) ${ }^{[19]}$ reported that GDP at the district level is significantly explained by night lights in the area. Waters et al., $(2018)^{[20]}$ have expressed that the anthropocene epoch is potential to find a place in the International Chronostratigraphic Chart (ICC). 


\section{Methods and methodology:-}

Light pollution (photo pollution), is increased by excessive illumination, misdirected or flashy at the presence of anthropogenic light in the night environment. It is the favourable effects of industrial development, urbanization by lighting pavements and parking places but it is blamed that health of livings and plants are affected. The typical pollution of the sky has alarming impact on human health, animals, birds, insects and plant kingdom in late 90's of $20^{\text {th }}$ century. We have lost the night sky and there is increased nocturnal activities and lost the tranquility and disturbed melancholies of night. Stars of the assemblages - Saptarishi, Dhruba, Leo, Scorpio and many others are no longer visible in naked eye as the result of light pollution in cities of India.

Garstang Roy $1986^{[21]}$ was first to introduce a modeling technique, to estimate the brightness of the night-sky in and around at a random zenith expanses. He assumed a dome of uniform brightness considering the total brightness related to city demography. Both molecular and aerosol scattering were taken where quantity of aerosols was a variable parameter. He constructed various scale heights and considered the reflectivity of the ground and the part of the light radiated parallel to the ground. He applied it to many a cities and modified the model in subsequent years (1986 to 2000) to calculate the night sky brightness. Cinzani P., (2004) ${ }^{[22]}$ had modified the Garstands model to the satellite's high-resolution gauging of upward flux of the artificial light of sky. He took the help of Meteorological Satellite Program of Air Force Defense Operation of US Line scan System and to a global digital elevation model (GTOPO30) taken by the US Geological Survey's EROS Data Centre. The digital elevation data were used to predict the distribution of night sky brightness at a place.

NOAA, prepared satellite maps to measure the brightness of the sky. Latter NOAA included the light pollution like SQM/SQC in their World Atlas (Earth Observation Group, NOAA National Geophysical Data Center). The data received from the NOAA VIIRS/DMSP world atlas have been used for study the light pollution of India. www.lightpollutionmap.info employed a mapping to display/World Atlas overlays (road and hybrid Bing maps)

\section{The night sky surveillance:-}

The Greece Astronomer, Hipparchus, 2200 YBP, classified visible stars into six categories according to their magnitude. Assigned magnitude of 1.0 to the brightest and magnitude of 6.0, the faintest. But germination of LP started after Edision 1879 i.e after invention of electricity. Besides visible light pollution (Infrared), the X-ray, $\Upsilon$ ray and radio light can also cause pollutions and affect human and health of livings. To sky observerscan valuate the true darkness of an area nrotle developed a nine-level scale Fig 2.

\section{Naked-eye Limiting Magnitude (NLM):}

It designates the visibility of indistinct stars. The large the magnitude number and distance from earth the star becomes dimmer. Each whole number represents a factor of 5 in brightness. For example the magnitude 5 star looks five times brighter than a magnitude of 6 stars, while a magnitude 4 star appears ten times brighter than a magnitude 6 star. The milk way (MW), the galaxy M33 is an obvious naked-eye object. Night Time light (NTL) data have been observed by the Defense Meteorological Satellite Program (DMSP) by Operational Line Scan System (OLS) from 1972 but could not be public till 1992. The surveillance of NTL images of the Earth have been obtained from the DMSP was given by Woodruff Sullivan in 1989. But since 1992 data are available which provide quantitative information on the upward flux emitted by sources. However satellite data don't give any direct information on the effects of this light flux on the night sky due to light pollution propagation. The aim of our work is to study these effects.

\section{Brotle Dry Sky Scale:}

Bortle J, 2001 in Sky \& Telescope magazine gave the scale to quantify the darkness of the sky and named it as, "the Bortle Dark-Sky Scale" can be used for measuring night pollution. The 1-9 numbered scale is in increasing order of disturbed nadir and signify the quantity of night pollution.

1. Brotle dry sky scale is a ruler that measures the brightness of night sky of a nadir of a particular place.

2. Naked eye visibility of Saptrasi mandal and Ursa minor (The great bear) are at the bottom (Scale 8 \& 9).

3. The quantification of the observability of sky can be done by this scale.

4. The visibility of Milky way, Zodiacal light, and the galxy and clusters like M 4, M 5, M15, M22 and M33 are the basis for classification in the scale https://darkskydiary.wordpress.com/2012/01/19/the-bortle-scale-a-flow-chart/. 


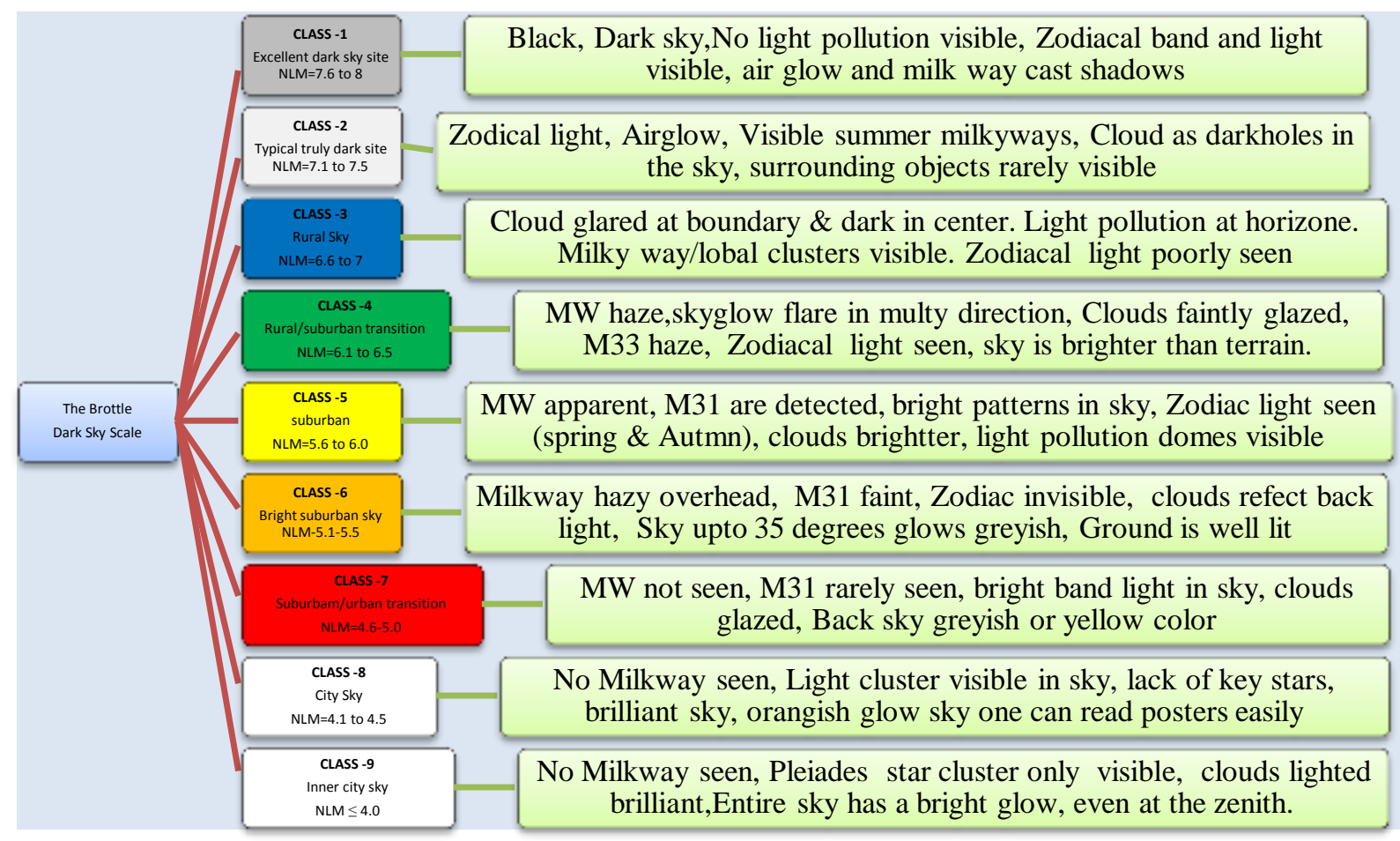

Fig 2:- Bortle dry-sky Scale gauge to scale light pollution (nine-level rating) that measures sky quality

The DMSP satellite F12 is in a low earth polar orbit and carries an oscillating scan radiometer, the Operational Linescan System (OLS), with a photomultiplier tube (PMT) as detector. The OLS scans a narrow swath of the Earth, about 3,000 km wide, perpendicular to the orbit and as the satellite moves it constructs a bi-dimensional image of the Earth surface Cinzano et al., (2004) ${ }^{[22]}$ and Cinzano and Elvidge (2004) ${ }^{[23]}$. The SQM meter used for measuring night pollution has the advantages of quantitative monitoring sky brightness, comparison of night brightness, finding the nights having faintest fuzziest, calibration of light pollution by Bortle scale, correlation between sky brightness and solar cycle, sunspot activity and Milankovitch results. CCD and CMOS camera users can find some analog to digital (ADC) level. The time series data can help our successors to find brightness prediction when our children in cities shall forget the starry sky http://unihedron.com/projects/darksky.

The Milky Way is unseen to $33 \%$ human in the Anthropocene epoch and more than $23 \%$ of the land surfaces of the world in mid-latitudes between $75^{\circ} \mathrm{N}$ and $60^{\circ} \mathrm{S}$. Interactive world light pollution map of Zenith sky brightness information using NOAA/EOG VIIRS/DMSP (2010, 2013, 2014, 2015, 2016, 2017), World Atlas 2015 overlays and SQM ((Sky quality meter) overlay have been considered. The technique uses two base layers, the road and hybrid Bing maps. The comparative scientific logic has been identified for eight night pollution affected cities in India were identified where relevant data are available but less analyzed. The comparative results and resolutions can prompt for amelioration, the comparison of the bright ness information and ratio of natural brightness to artificial of the major susceptible cities of India is in Fig -3 and Table 2.

Table 2:- Zenith sky brightness information of maximum brightness and artificial brightness at elevation and as per Bortle Dark-Sky Scale classification of different developing cities of India

\begin{tabular}{|c|c|c|c|c|c|c|c|c|}
\hline \# & City & Coordinate & $\begin{array}{l}\text { SQM/square } \\
\text { arc second. }\end{array}$ & $\begin{array}{l}\text { Bright } \\
\text { ness }\end{array}$ & $\begin{array}{l}\text { Artificial } \\
\text { brightness }\end{array}$ & Ratio & Elev $^{\mathrm{n}}$ & $\begin{array}{l}\text { Bortle } \\
\text { class }\end{array}$ \\
\hline $\mathrm{I}$ & II & III & IV & $\mathrm{V}$ & VI & VII & VIII & IX \\
\hline I & & $\begin{array}{l}\text { Latitude/ } \\
\text { Longitude }\end{array}$ & $\begin{array}{l}\text { mag./arc } \\
\sec ^{2}\end{array}$ & $\mathrm{mcd} / \mathrm{m}^{2}$ & $\mu \mathrm{cd} / \mathrm{m}^{2}$ & $\begin{array}{l}\text { Col V/ } \\
\text { col VI }\end{array}$ & mtrs & Class \\
\hline 1 & New Delhi & $\begin{array}{l}28^{\circ} 38^{\prime} 37^{\prime \prime} \mathrm{N} / \\
77^{\circ} 11^{\prime} 53^{\prime \prime} \mathrm{E}\end{array}$ & 17.90 & 7.45 & 7270 & 42.5 & 238 & class $8-9$ \\
\hline 2 & Calcutta & $22^{\circ} 33^{\prime} 36^{\prime \prime} \mathrm{N} /$ & 17.87 & 7.65 & 7480 & 43.7 & 08 & class 8-9 \\
\hline
\end{tabular}




\begin{tabular}{|l|l|l|l|l|l|l|l|l|}
\hline & & $88^{\circ} 21^{\prime} 54^{\prime \prime} \mathrm{E}$ & & & & & & \\
\hline 3 & Bhubaneswar & $\begin{array}{l}20^{\circ} 16^{\prime} 26^{\prime \prime} \mathrm{N} / \\
85^{\circ} 49^{\prime} 39^{\prime \prime} \mathrm{E}\end{array}$ & 18.86 & 3.08 & 2910 & 17.0 & 57 & class -7 \\
\hline 4 & Chennai & $\begin{array}{l}13^{\circ} 09^{\prime} 56^{\prime \prime} \mathrm{N} / \\
80^{\circ} 16^{\prime} 53^{\prime \prime} \mathrm{E}\end{array}$ & 18.33 & 5.01 & 4840 & 28.3 & 06 & class 8-9 \\
\hline 5 & Bengaluru & $\begin{array}{l}12^{\circ} 59^{\prime} 53^{\prime \prime} \mathrm{N} / \\
77^{\circ} 31^{\prime} 50^{\prime \prime} \mathrm{E}\end{array}$ & 18.06 & 6.46 & 6290 & 36.8 & 890 & class 8-9 \\
\hline 6 & Hyderabad & $\begin{array}{l}17^{\circ} 22^{\prime} 22^{\prime \prime} \mathrm{N} / \\
78^{\circ} 27^{\prime} 03^{\prime \prime} \mathrm{E}\end{array}$ & 17.83 & 7.96 & 7790 & 45.6 & 513 & class 8-9 \\
\hline 7 & Mumbai & $\begin{array}{l}19^{\circ} 03^{\prime} 33^{\prime \prime} \mathrm{N} / \\
72^{\circ} 51^{\prime} 17^{\prime \prime} \mathrm{E}\end{array}$ & 18.36 & 4.91 & 4740 & 27.7 & 09 & class 8-9 \\
\hline 8 & Ahmadabad & $\begin{array}{l}23^{\circ} 04^{\prime} 26^{\prime \prime} \mathrm{N} / \\
72^{\circ} 35^{\prime} 19^{\prime \prime} \mathrm{E}\end{array}$ & 18.71 & 3.56 & 3380 & 19.8 & 53 & class -7 \\
\hline
\end{tabular}

From the above data the following conclusions can be drawn:

i. The city Hyderabad has maximum brightness and also artificial brightness and suffering from highest light pollution in India followed by Calcutta and then New Delhi.

ii. The radiance and brightness also follows the artificial lightening hence the light pollution.

iii. The graph shows there is linear relationship between the brightness and the ratio between the brightness and artificial lightening. (shown in graph )

iv. The night pollution of the sky is considered most of the cities come under the class 8-9 (Brotle class)



Fig 3:- Brightness, maximum brightness to artificial brightness and SQM in eight major cities in India

\section{Decadal radiance information:-}

The mega cities of India has lost their night, there is health risk of its citizen and affecting the health of surrounding noctural animals. The nadir is becoming brighter at night than before forced the living kingdome to disturb their biological clock. The radiation information of major cities of India measured by Sky Quality Meter (SQM) given in world atlas $-(2015)^{[24]}$ is given in Table 3 .

Table 3:- Radiance information of the major cities of India for radiance $\left(10^{-9} \mathrm{~W} / \mathrm{cm}^{2} * \mathrm{Sr}\right)$ byVIIRS for the month of March was 2014, 2015,2016 and 2017

\begin{tabular}{|c|c|c|c|c|c|c|}
\hline \multirow[t]{2}{*}{$\#$} & $\begin{array}{l}\text { India/ } \\
\text { city }\end{array}$ & 2013 & 2014 & 2015 & 2016 & 2017 \\
\hline & & $\begin{array}{l}\text { Radiance 10-9 W/ } \\
\mathrm{cm}^{2} * \text { Sr} / \text { Height }(\mathrm{m})\end{array}$ & $\begin{array}{l}\text { Radiance10-9W/ } \\
\mathrm{cm}^{2} * \text { Sr/Height (m) }\end{array}$ & $\begin{array}{l}\text { Radiance } 10^{-9} \mathrm{~W} / \\
\mathrm{cm}^{2} * \mathrm{Sr} / \text { Height }(\mathrm{m})\end{array}$ & $\begin{array}{l}\text { Radiance10-9W/ } \\
\mathrm{cm} 2 * \mathrm{Sr} / \text { Height }(\mathrm{m})\end{array}$ & $\begin{array}{l}\text { Radiance10-9W/ } \\
\mathrm{cm} 2 * \text { Sr/Height }(\mathrm{m})\end{array}$ \\
\hline 1 & $\begin{array}{l}\text { New } \\
\text { Delhi }\end{array}$ & $\begin{array}{l}68.9 / 218 \mathrm{~m}, 28^{0} 39^{\prime} \\
07^{\prime} \mathrm{N} 77^{0} 08^{\prime} 27^{\prime}{ }^{\prime} \mathrm{E}\end{array}$ & $\begin{array}{l}96.34 / 209 \mathrm{~m}, 28^{0} 39^{\prime} \\
22^{\prime} \mathrm{N} 77^{0} 12^{\prime} 13^{\prime \prime} \mathrm{E}\end{array}$ & $\begin{array}{l}101 / 219 \mathrm{~m}, 28^{0} \quad 38^{\prime} \\
00^{\prime} \mathrm{N} 77^{0} 13^{\prime} 15^{\prime \prime} \mathrm{E}\end{array}$ & $\begin{array}{l}137.08 / 224 \mathrm{~m}, 28^{0} 33 \\
' 21 " \mathrm{~N} 77^{0} 05^{\prime} 17^{\prime \prime} \mathrm{E}\end{array}$ & $\begin{array}{l}142.5 / 216 \mathrm{~m}, 28^{0} 34^{\prime} \\
20^{\prime \prime} \mathrm{N} 77^{0} 12^{\prime} 41^{\prime \prime} \mathrm{E}\end{array}$ \\
\hline 2 & Calcutt & $69.3 / 209 \mathrm{~m}, 28^{0} 39^{\prime}$ & $77.3 / 14 \mathrm{~m}, 22^{0} 34^{\prime} 07$ & $65.08 / 10 \mathrm{~m}, 22^{0} 34^{\prime} 3$ & $66.95 / 7 \mathrm{~m}, 22^{0} 34^{\prime} 01^{\prime \prime}$ & $62.43 / 8 \mathrm{~m}, 22^{0} 32^{\prime} 36^{\prime \prime}$ \\
\hline
\end{tabular}




\begin{tabular}{|c|c|c|c|c|c|c|}
\hline & a & 'E & $\mathrm{L}$ & ' $\mathrm{s}$, & $1 \mathrm{~N}$, oO 2 & \\
\hline 3 &  & $\begin{array}{l}0.7 / 65 m, 20^{0} 14 ' \\
8^{\prime}{ }^{\prime}+7^{0} 14^{\prime} 23 ” ' E\end{array}$ & $\begin{array}{l}\text { 6' } \\
\text { 3”'E }\end{array}$ & $\begin{array}{l}6^{\prime} \\
4 " \mathrm{E}\end{array}$ & $\begin{array}{l}34.96 / 58 \mathrm{~m}, \\
31{ }^{\prime} \mathrm{N} 85^{0} 4\end{array}$ & $\begin{array}{l}41.63 / 64 \mathrm{~m}, 20^{0} 16^{\prime} \\
17{ }^{\prime} \mathrm{N} 85^{0} 49^{\prime} 46^{\prime \prime} \mathrm{E}\end{array}$ \\
\hline 4 & & $\begin{array}{l}82.7 / 4 \mathrm{~m}, 13^{0} \quad 49^{\prime} \mathrm{N} \\
80^{\circ} 16^{\prime} 51^{\prime \prime} \mathrm{E}\end{array}$ & $\begin{array}{l}94.7 / 4 \mathrm{~m}, 13^{0} 05^{\prime} \\
13{ }^{\prime} \mathrm{N} 80^{0} 17^{\prime} 36^{\prime \prime} \mathrm{E}\end{array}$ & $\begin{array}{l}\text { 101/4m,1306' } 13^{\circ} " \\
\text { N } 80^{\circ} 17^{\prime} 45^{\prime \prime} \mathrm{E}\end{array}$ & $\begin{array}{l}316.03 / 10 \mathrm{~m}, 13^{0} 09^{\prime} \\
22^{\prime \prime} \mathrm{N} 80^{0} 16^{\prime} 58^{\prime \prime} \mathrm{E}\end{array}$ & $\begin{array}{l}420.19 / 06 \mathrm{~m}, 13^{0} 09^{\prime} \\
49^{\prime \prime} \mathrm{N} 80^{\circ} 17^{\prime} 03^{\prime \prime} \mathrm{E}\end{array}$ \\
\hline 5 & & & $72.05 / 910 \mathrm{~m}, 13^{0} 01^{\prime \prime}$ & $\begin{array}{l}\text { 135.93/890m, } \\
0^{\prime} 19 \text { "N } 77^{0} 31\end{array}$ & $\begin{array}{l}\text { 103.61/926m, } 13^{0} 00^{\prime \prime} \\
41^{\prime \prime N} 77^{0} 30^{\prime} 14^{\prime \prime} \mathrm{E}\end{array}$ & $\begin{array}{l}\text { 109.29/893m,1300" } \\
02^{\circ} \mathrm{N} 77^{0} 31^{\prime} 066^{\prime \prime} \mathrm{E}\end{array}$ \\
\hline 6 & & & $\begin{array}{l}85.92 / 524 \mathrm{~m}, 17^{0} 20 \\
54^{\prime}{ }^{\prime} 7^{0} 28^{\prime} 05^{\prime \prime} \mathrm{E}\end{array}$ & $\begin{array}{l}150.7 / 503 \mathrm{~m}, 17^{0} 22 \\
25^{\prime} \mathrm{N} 78^{0} 27^{\prime} 23^{\prime \prime} \mathrm{E}\end{array}$ & $\begin{array}{l}104.2 / 521 \mathrm{~m}, 17^{0} \quad 22 \\
42^{\prime \prime N} 78^{0} 27^{\prime} 23^{\prime \prime} \mathrm{E}\end{array}$ & $\begin{array}{l}142.95 / 525 \mathrm{~m}, 17^{0} 22 \\
38^{\prime}{ }^{\prime} 78^{0} 27^{\prime} 12^{\prime} \mathrm{E}\end{array}$ \\
\hline 7 & $\begin{array}{l}\text { Bomba } \\
\text { y }\end{array}$ & $\begin{array}{l}\text { 69.68/12m,1900" } \\
44^{\prime} \mathrm{N} 72^{0} 49^{\prime} 15^{\prime \prime} \mathrm{E}\end{array}$ & $\begin{array}{l}107.39 / 10 \mathrm{~m}, 19^{0} 06^{\prime} \\
04{ }^{\prime} 2^{0} 52^{\prime} 27^{\prime \prime} \mathrm{E}\end{array}$ & $\begin{array}{l}124.27 / 10 \mathrm{~m}, 19^{0} 06^{\prime} \\
08^{\prime} \mathrm{N} 72^{0} 52^{\prime} 25^{\prime} \mathrm{E}\end{array}$ & $\begin{array}{l}135.61 / 10 \mathrm{~m}, 19^{0} 06^{\prime} \\
04^{\prime \prime} \mathrm{N} 72^{0} 52^{\prime} 33^{\prime \prime} \mathrm{E}\end{array}$ & $\begin{array}{l}227.27 / 20 \mathrm{~m}, 19^{0} 00^{\prime} \\
55^{\prime \prime} \mathrm{N} 72^{\circ} 54^{\prime} 21^{\prime \prime} \mathrm{E}\end{array}$ \\
\hline 0 & ad & $\begin{array}{l}94.48 / 04 \mathrm{~m}, 21^{0} \quad 04^{\prime} \\
21^{\prime \prime} \mathrm{N} 72^{0} 37^{\prime} 21^{\prime \prime} \mathrm{E}\end{array}$ & $\begin{array}{l}99.08 / 09 \mathrm{~m}, 23^{0} \quad 04^{\prime} \\
09^{\prime \prime N} 72^{0} 36^{\prime} 57^{\prime \prime} \mathrm{E}\end{array}$ & $\begin{array}{l}137.09 / 54 \mathrm{~m}, 23^{0} 04^{\prime} \\
14^{\prime \prime} \mathrm{N} 72^{0} 37^{\prime} 18^{\prime \prime} \mathrm{E}\end{array}$ & $\begin{array}{l}148.22 / 53 \mathrm{~m}, 23^{0} \\
19^{\prime} \mathrm{N} 72^{0} 37^{\prime} 15^{\prime \prime} \mathrm{E}\end{array}$ & $\begin{array}{l}127.35 / 53 \mathrm{~m}, 23^{0} \quad 04^{\prime} \\
19^{\prime \prime} \mathrm{N} 72^{0} 37^{\prime} 15^{\prime \prime} \mathrm{E}\end{array}$ \\
\hline
\end{tabular}

The radiation was considered from the year 2014 to 2017 and it was found that the Chenei cit of India are gradually increasing in their Radiance (10-9 W/cm2*Sr) and is the highest in India though it is varrying from year to year. From the VIIRS (SQM) data it is found the anthropogencally developing cities like Chenei,Delhi, Hyderabad and Ahamadabad have increasednatural radiation and expected to rise their LP.

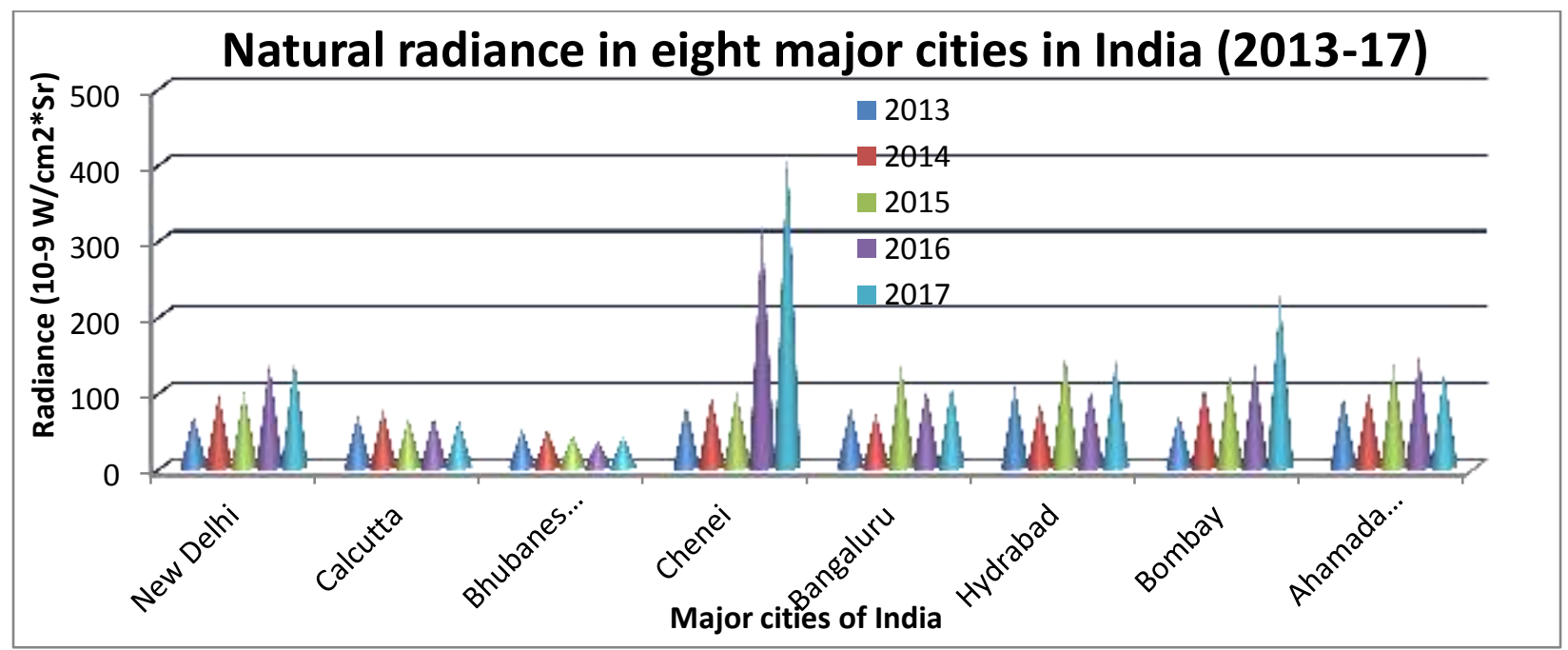

Fig 4:- Natural radiance in $\left(10^{-9} \mathrm{~W} / \mathrm{cm}^{2} * \mathrm{Sr}\right)$ major cities in India (2013-17) (Source:NOAA VIIRS (SQM) data)

The radiance information is obtained systematically from 2013 and considered as base year. The average radiance of eight major cities (NewDelhi, Calcuatta, Bhubaneswar, Chenei, Bangaluru, Mumbai and Ahamadabad) was $112.13 \times 10^{-9} \mathrm{~W} / \mathrm{cm} 2 * \mathrm{Sr}$. If 2013 is taken as base year the average rise in radiance is $102.23 \%$ which is alraming not only for the homosapiens but also for the flora and fauna in India.

\section{LP and other Forms of Radiation:-}

$\mathrm{X}$-ray, $\gamma$ - ray and UV radiation from different sources is harmful to human and living beings by high radiation and photopollution.Melatonin, the natural sleep regulating hormone, a biological receptor decreases its secretion during light pollution at night sky. The nocturnal activities of human and animals are supressed under decreased dark night sky condition. Melatonin is also involved in the regulation of the vitaletheine modulators, the flavin-containing microsomal mixed-function monooxygenase. The monooxygenase is the cause for whyand how radiation suppresses the immune response and causes cancer. Radiation breaks an essential cofactor in the monooxygenase, riboflavin, into either lumichrome or lumiflavin, depending upon the conditions of exposure. Blistering of the skin is the result of the exposure. However the intensities of light appropriate for affecting the total dark organism and for affecting melatonin production is yet to be known Posch et al., $(2003)^{[25]}$. 


\section{How night sky is polluted:-}

Natural lighting levels are governed by celestial sources like the Moon, the stars and the Milky Way, and zodiacal light of sky at night. LP has increased the luminance of sky due to artificial lighting in the Anthropocene epoch. The moonless nights, the clear sky has the luminance far from the Milky Way and zodiacal light is about 22 $\left(\mathrm{mag} / \mathrm{arcsec}^{2}\right)$ or $\approx 1.7 \times 10-4 \mathrm{~cd} / \mathrm{m}^{2}\left(\mathrm{mag} / \mathrm{arc} \mathrm{sec}^{2}\right.$ is magnitude per square arcsecond in the Johnson-Cousins Vband -2). The colour code used for artificial brightness of the sky in Atlas is given in Table 4.

Table 4:- Levels of artificial brightness of night sky ( lumen) under different condition (http://advances Science mag.org/content/2/6/e1600377)

\begin{tabular}{|l|l|l|l|l|}
\hline $\begin{array}{l}\text { S1 } \\
\text { No }\end{array}$ & Condition of sky & Luminance & $\begin{array}{l}\% \text { above } \\
\text { natural light }\end{array}$ & Remarks \\
\hline 1 & Prestine & $1.7 \mu \mathrm{cd} / \mathrm{m}^{2}$ & $0-1 \%$ & $\begin{array}{l}\text { Areas safe, scenic, horizon glow has major impact on } \\
\text { solitude and no light pollution }\end{array}$ \\
\hline 2 & Dark gray level & $\begin{array}{l}1.7-3.4 \mu \mathrm{cd} / \mathrm{m}^{2} \\
\text { upto } 14 \mu \mathrm{cd} / \mathrm{m}^{2}\end{array}$ & $\begin{array}{l}1-2 \% \quad \text { upto } \\
8 \%\end{array}$ & $\begin{array}{l}\text { Relatively clear at the zenith but degraded toward the } \\
\text { horizon. Protect the area from future rise in light } \\
\text { pollution }\end{array}$ \\
\hline 3 & Blue & $\begin{array}{l}13.6 \quad 27.2 \\
\text { upto } 14 \text { to } 87 \\
\mu \mathrm{cd} / \mathrm{m} 2\end{array}$ & $\begin{array}{l}8-16 \% \quad \text { upto } \\
50 \%\end{array}$ & $\begin{array}{l}\text { Sky likely unpolluted at zenith but polluted toward the } \\
\text { horizon astronomically, Recomm-1 (IAU } \\
\text { Commission 50), polluted sky degraded to the zenith }\end{array}$ \\
\hline 4 & $\begin{array}{l}\text { Yellow (winter) } \\
\text { Orange (Summer) }\end{array}$ & $\begin{array}{l}\text { med/m upto } 87 \\
\text { to } 688 \mu \mathrm{cd} / \mathrm{m}^{2}\end{array}$ & $>50 \%$ & $\begin{array}{l}\text { winter Milky Way (faint in summer) Milky Way } \\
\text { faintly seen in the light of sky, Star Cloud of } \\
\text { Sagittarius only visible, natural appearance of the sky } \\
\text { is lost }\end{array}$ \\
\hline 5 & Red & $\begin{array}{l}1 \mathrm{mcd} / \mathrm{m} 2 \text { or } \\
688 \text { to 3000 } \\
\mu \mathrm{cd} / \mathrm{m} 2\end{array}$ & $\begin{array}{l}\text { scotopic to } \\
\text { mesopic } \\
\text { vision }\end{array}$ & $\begin{array}{l}\text { same luminosity as a pristine sky at the end of nautical } \\
\text { twilight (1.4 mcd/m2), night adaptation is no longer } \\
\text { possible for human eyes }\end{array}$ \\
\hline
\end{tabular}

From the data given by Fabio Falchi et al., (2016) ${ }^{[9]}$ it indicates that the light pollution by area is safe for the globe except some countires like EU, Italy, South Korea, France and UK. The intensity of LP considering demography is highly vulnerable and alraming in the present Anthropocene Epoch. The human, most of the bovines, animals in forests and freshwater aqua habitats in the urban area are suffering from LP. Milky Way is faintly seen in the night sky but the star Sagittarius Cloud is only visible in the earth at night. He has classified the light pollution (LP) of the G-20 group of countries according to their population or area wise and the status of the countries of the world living under the light polluted sky is given in Table 5.

Table 5:- The status of the countries in the globe living under the light polluted sky, (from light pollution atlas made by Fabio Falchi et al., (2016) ${ }^{[9]}$

\begin{tabular}{|c|c|c|c|c|c|c|c|c|c|}
\hline \multirow{2}{*}{$\begin{array}{l}\text { (EU) G-20 } \\
\text { Countries }\end{array}$} & \multicolumn{3}{|c|}{ Oder of LP by area } & \multicolumn{3}{|c|}{ Order of LP by population } & \multicolumn{2}{|c|}{ Cities in order of LP } & \multirow{2}{*}{$\begin{array}{l}\text { Remark } \\
\text { Countries } \\
\text { Trend/year } \\
1992 \text { to } \\
2013\end{array}$} \\
\hline & $\begin{array}{l}\mathrm{ran} \\
\mathrm{k}\end{array}$ & $\begin{array}{l}\text { LP Zone } \\
\text { in } \\
\mu \mathrm{cd} / \mathrm{m}^{2}\end{array}$ & $\begin{array}{l}\text { Approx } \\
\text { Max \% } \\
\text { LP zone }\end{array}$ & $\begin{array}{l}\text { Ran } \\
\mathrm{k}\end{array}$ & $\begin{array}{l}\text { Zone of LP } \\
\mu \mathrm{cd} / \mathrm{m}^{2}\end{array}$ & $\begin{array}{l}\text { Max \% } \\
\text { polluted } \\
\text { zone }\end{array}$ & $\begin{array}{l}\text { Rank } \\
\text { highly LP } \\
\text { states by } \\
\text { population }\end{array}$ & $\begin{array}{l}\text { Least LP } \\
\text { states } \\
\text { in order }\end{array}$ & \\
\hline Italy & 01 & 87 to 688 & $70-72 \%$ & 10 & $688-3000$ & $45-50 \%$ & Singapur & Chad & $+@ 0.71 \%$ \\
\hline S. Korea & 02 & 87 to 688 & $68-72 \%$ & 02 & $>3000$ & $65-70 \%$ & Kwait & Cent. Africa. & $+@ 0.89 \%$ \\
\hline Germany & 03 & 87 to 688 & $65-70 \%$ & 18 & 87 to 688 & $50-55 \%$ & Kartar & Madgascar & - @ $0.28 \%$ \\
\hline France & 04 & 87 to 688 & $55-60 \%$ & 11 & 87 to 688 & $37-42 \%$ & UAE & Gunea & $+@ 0.43 \%$ \\
\hline U K & 05 & 87 to 688 & $47-52 \%$ & 12 & 68to 3000 & $50-55 \%$ & S. Arbia & Somalia & $-@ 1.53 \%$ \\
\hline Spain & 06 & $14-87$ & $50-55 \%$ & 05 & $>3000$ & $40-45 \%$ & S. Korea & Ethiopia & $+@ 1.03 \%$ \\
\hline Japan & 07 & $14-87$ & $50-54 \%$ & 09 & 688 to 3000 & $50-55 \%$ & Israel & Liberia & $-@ 0.94 \%$ \\
\hline India & 08 & $14-87$ & $45-50 \%$ & 18 & 87 to 688 & $35-40 \%$ & Argentina & Niger & $+@ 2.3 \%$ \\
\hline US & 09 & $<1.7$ & $40-45 \%$ & 06 & 688 to 3000 & $40-50 \%$ & Libya & Leone & $-@ 0.98 \%$ \\
\hline S. Arabia & 10 & $<1.7$ & $35-40 \%$ & 01 & $>3000$ & $80-85 \%$ & Trinidad & Congo & $+@ 2.36 \%$ \\
\hline Mexico & 11 & $1.7-14$ & $40-45 \%$ & 13 & 688 to 3000 & $33-38 \%$ & Iraq & Burubdi & $+@ 0.67 \%$ \\
\hline China & 12 & $<1.7$ & $45-50 \%$ & 15 & 87 to 688 & $30-35 \%$ & Canada & Guinea & $+@ 3.45 \%$ \\
\hline S. africa & 13 & $<1.7$ & $38-40 \%$ & 16 & 688 to 3000 & $35-40 \%$ & Brunei & Papua & $+@ 0.74$ \\
\hline Indonoasia & 14 & $<1.7$ & $60-65 \%$ & 17 & 87 to 688 & $38-42 \%$ & West bank & Eritria & +@1.54\% \\
\hline
\end{tabular}




\begin{tabular}{|l|l|l|l|l|l|l|l|l|l|}
\hline Argentina & 15 & $1.7-14$ & $38-42 \%$ & 03 & $>3000$ & $55-60 \%$ & Greece & Mali & +@ 1.78\% \\
\hline Brazil & 16 & $<1.7$ & $50-55 \%$ & 07 & $>3000$ & $30-35 \%$ & Gibralter & Tanzania & $+@ 1.89 \%$ \\
\hline Russia & 17 & $<1.7$ & $65-70 \%$ & 08 & $>3000$ & $30-35 \%$ & Malta & Solomon Is. & -@ 1.03\% \\
\hline Canada & 18 & $<1.7$ & $80-85 \%$ & 04 & $>3000$ & $45-50 \%$ & Spain & Tanzania & - $3.02 \%$ \\
\hline Australia & 19 & $<1.7$ & $85-90 \%$ & 14 & 688 to 3000 & $50-55 \%$ & Chile & Uganda & \\
\hline EU & 20 & 87 to 688 & $40-45 \%$ & 20 & 688 to 3000 & $35-40 \%$ & Iceland & Sudan & $+@ 0.28 \%$ \\
\hline Globe & & $<1.7$ & $60-65 \%$ & & 87 to 688 & $25-30 \%$ & $\begin{array}{l}\text { Developed } \\
\text { countries }\end{array}$ & $\begin{array}{l}\text { Undevelope } \\
\text { d countries }\end{array}$ & \\
\hline
\end{tabular}
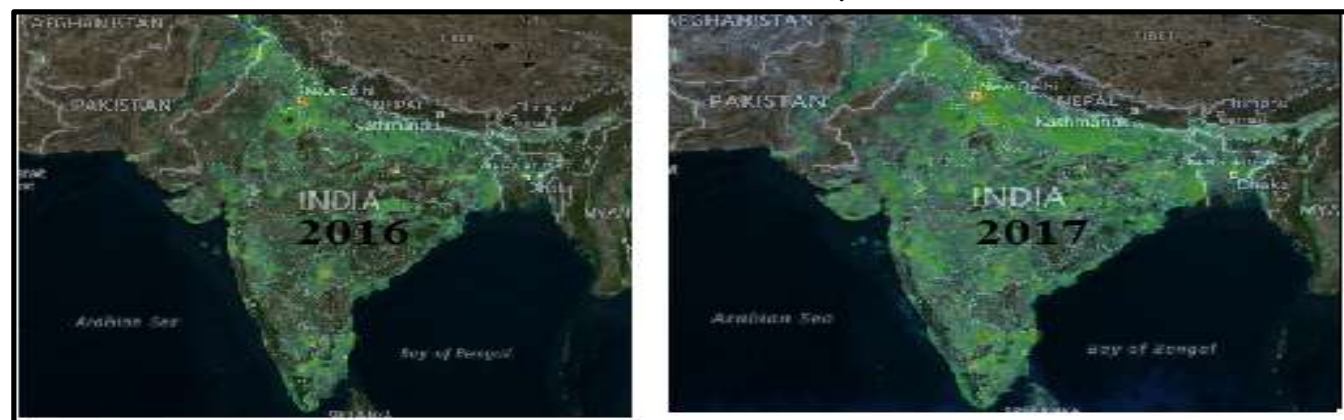

Unit:Radi ance $10^{-9}$

$W / \mathrm{cm}^{2} \mathrm{Sr}$ https://w ww.light pollution map.info /\#zoom= 3 \&lat $=44$ o0864\&l
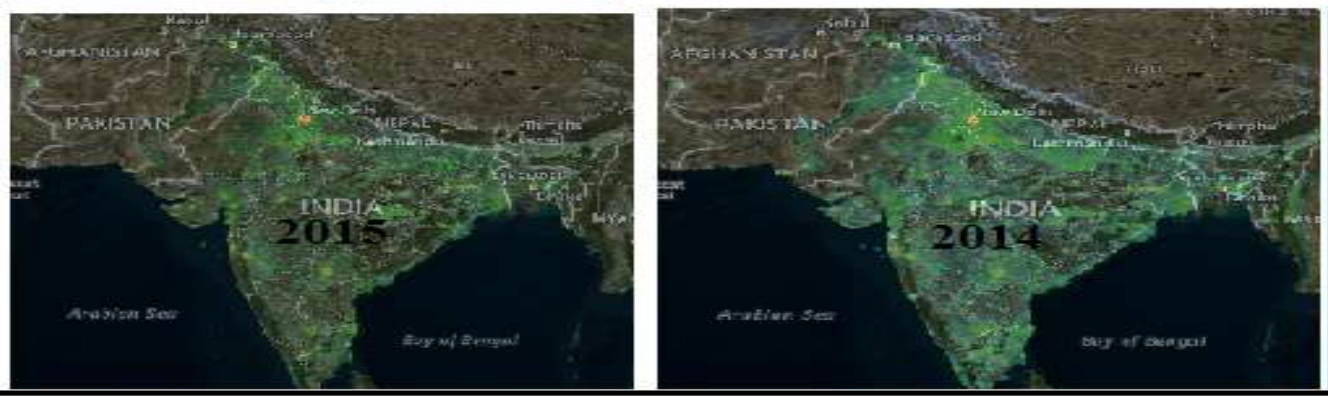

on $=9004$

Fig 5:- The NOAA/EOG VIIRS/DMSP/withoverlays map of India ( 2014-18), https://www.google.co.in/search?)

Table 5 indicate that the order in rate of increasing pollution of LP G-20 countries like China, SAE and India being increasing @ 3.45\%,2.36\% and 2.3\% respectively. Similarly the Lp of the G-20 countries of the globe Canada, UK and Russia are in the decreasing trend @ 3.02\%, -1.53\% and -1.03\% respectively. It is high time for China, SAE, and India to think of fighting their LP problem.Considering the radiation of India per thousand population was 8.9, 10.1, 7.0, 9.5 and $12.0(\mu \mathrm{cd} / \mathrm{m} 2)$ in the years $2013,2014,2015,2016$ and 2017 respectively. They are in the yellow colour zone as winter faint Milky Way and in summer in hazy illuminant sky. Star Cloud of Sagittarius is only visible. Natural appearance of the sky is lost https://www.lightpollutionmap.info/stats/\#zoom=3\&lat = $2492924 \& l o n=9217688$ and the sum of DMSP DN (average digital Number) values are reported and the graph is drawn Fig 5 and fig 6 and Tab 5.

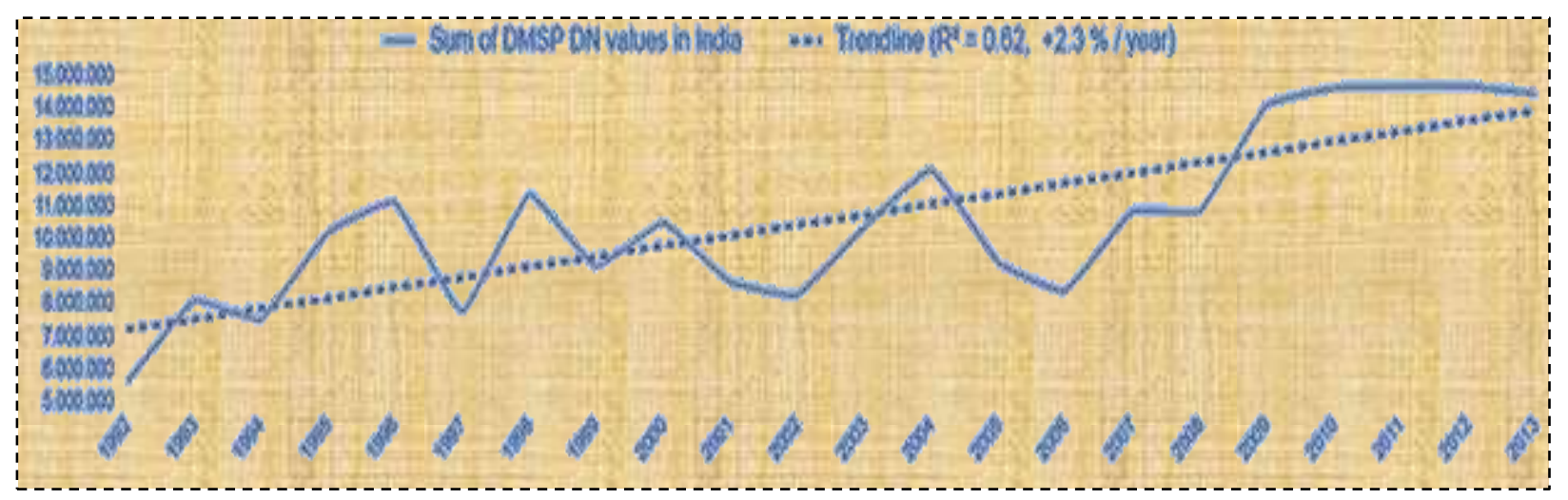

Figure 6:- The DMSP DN map of India data 1992-2013 (Source: https://www.lightpollutionmap.info/stats4 \&lon=9217688) 


\section{Ill effects of light pollution:-}

Light plays positive role in metabolism activities of living species like photosynthesis, partitioning Day vs. night activities, organisms to heal and recuperate their DNA from damage, maintaining spatial orientation, circadian clock and photo- periodism and visual perception. But excess of artificial light (LP) is one from the specific destructive disorder like over-illumination, Glare, Light Clutter, sky glow and light trespass that harms the living kingdom.

1. UV and IR cause carcinoma and affect eye and skin by UVA and UVB can penetrating power is high. The most biologically active zone (Actinic region) is of wave length 200 to $310 \mathrm{~nm}$. Outdoor workers (Construction, survey and supervisors), painters, physiotherapist, Disco dancers, Plasma torch operators, photo-litho-graphers and men in agriculture, forestry and fishing are prone /affected by UV exposure.

Tab 6:- Different zones of hazardous ultraviolet light to biological system and protective measures (https: //safety.dept.shef.ac.uk/ir/uvsafety.pdf)

\begin{tabular}{|c|c|c|c|c|c|c|}
\hline \# & $\begin{array}{l}\text { Type } \\
\text { of } \\
\text { light }\end{array}$ & $\begin{array}{l}\text { Risky zone } \\
\text { /Ozone } \\
\text { layer } \\
\text { absorption }\end{array}$ & $\begin{array}{l}\lambda= \\
\text { Wave } \\
\text { length }\end{array}$ & $\begin{array}{l}\text { Source } / \% \quad \text { earth } \\
\text { surface absorption }\end{array}$ & Impact on health & Protection/Source of use \\
\hline $\mathrm{A}$ & (UV) & $\begin{array}{l}200- \\
310 \mathrm{~nm}\end{array}$ & $\begin{array}{l}400- \\
100 \mathrm{~nm}\end{array}$ & $\begin{array}{l}\text { outdoor work, } \\
\text { welding, printing and } \\
\text { curing/ } 100 \%\end{array}$ & $\begin{array}{l}\text { Causes all skin } \\
\text { cancer, changes in } \\
\text { cell growth, conju } \\
\text { nctivitis / keratitis, } \\
\text { wrinkling skin, DNA } \\
\text { damage, plastics } \\
\text { discolored \& cracked }\end{array}$ & $\begin{array}{l}\text { Opaque PPE, limited } \\
\text { access, warning signs, } \\
\text { mass training, avoid } \\
\text { Metal halide Hg \& photo } \\
\text { therapy lamps, Plasma } \\
\text { torches/ Triggers vitamin } \\
\text { D, Helps moods }\end{array}$ \\
\hline A-1 & UVA & $\begin{array}{l}200-310 \\
\mathrm{~nm} / \mathrm{nil}\end{array}$ & $\begin{array}{l}400- \\
315 \mathrm{~nm}\end{array}$ & $\begin{array}{l}\text { cosmetic tanning, } \\
\text { treatment psoriasis, } \\
\text { disco lights (Ni/ Co } \\
\text { oxide glass coated) } \\
\text { Hardening of inks and } \\
\text { coatings } / 98 \%\end{array}$ & $\begin{array}{l}\text { Tanning rays, ageing, } \\
\text { high risk of cancer, } \\
\text { darken of skin } \\
\text { melanin, cataract, } \\
\text { emit low levels UVA }\end{array}$ & $\begin{array}{l}\text { Pest control, Minimum } \\
\text { exposure time, max } \\
\text { distance from source, } \\
\text { effective shielding/ } \\
\text { counterfeit banknotes }\end{array}$ \\
\hline A-2 & UVB & $\begin{array}{l}280- \\
310 \mathrm{~nm} / \mathrm{mo} \\
\text { stly }\end{array}$ & $\begin{array}{l}315- \\
280 \mathrm{~nm}\end{array}$ & $\begin{array}{l}\text { trans illuminators at } \\
297 \mathrm{~nm} \text {, Harden of } \\
\text { inks \&coatings More } \\
\text { intense than UVA \& } \\
\text { UVC/ }<2 \%\end{array}$ & $\begin{array}{l}\text { Burning rays, fast-tan } \\
\text { ning, erythema - sun } \\
\text { burn, increase in pig } \\
\text { mentation skin burns, } \\
\text { erythema, risk of skin } \\
\text { cancer. }\end{array}$ & $\begin{array}{l}\text { Actinic region of } \mathrm{UV} \text {. } \\
\text { Exposure } \min ^{\mathrm{m}} \text { time, } \max \\
\text { distance and effective } \\
\text { shield/ treat psoriasis. }\end{array}$ \\
\hline A-3 & UVC & $\begin{array}{l}200- \\
280 \mathrm{~nm} / \\
\approx 100 \%\end{array}$ & $\begin{array}{l}280- \\
100 \mathrm{~nm}\end{array}$ & $\begin{array}{l}\text { germicidal lamps } \\
\text { operate at 254nm ,No } \\
\text { malignancy reported/ } \\
\text { almost nil }\end{array}$ & $\begin{array}{l}\text { Dangerous rays, } \\
\text { attenuate atmospheric } \\
\text { gases, destroys DNA/ } \\
\text { bacteria \& micro } \\
\text { organisms }\end{array}$ & $\begin{array}{l}\text { Germicidal in medicals \& } \\
\text { labs/disinfecting water } \\
\text { maintain safe distant.( } \\
\text { http://www.hko.gov. hk/ } \\
\text { m/ article_e.htm ?title } \\
=\text { ele_00127) }\end{array}$ \\
\hline B & IR & $\begin{array}{l}\text { IRA= } \\
760-1400 \\
\mathrm{~nm} \\
\mathrm{IRB}=1400 \\
-3000 \mathrm{~nm} \\
\mathrm{IRC}= \\
3000 \mathrm{~nm}-1 \\
\mathrm{~mm}\end{array}$ & $\begin{array}{l}700 \mathrm{~nm} \\
-1 \mathrm{~mm}\end{array}$ & $\begin{array}{lr}\text { biological } & \text { effects, } \\
\text { future } & \text { cold/hot } \\
\text { weather apparel \& } & \\
\text { sleeping mattress. } \lambda= \\
9.6 \mu \mathrm{m} \text { safe for } \\
\text { humans, increase } \\
\text { immunity, triggers } \\
\text { regeneration } \quad \& \\
\text { recovery of many } \\
\text { organs \&systems, }\end{array}$ & $\begin{array}{l}\text { premature skin aging, } \\
\text { skin damage due to } \\
\text { hyperthermia,(therma } \\
\text { l radiation), Cause: } \\
\text { rise temp. of brain by } \\
1^{\circ} \mathrm{C} \text {, dizziness; rise } \\
\text { heart rate; nausea; } \\
\text { darkening the eyes. } \\
>2^{\circ} \mathrm{C} \text { cause } \\
\text { meningitis }\end{array}$ & $\begin{array}{l}\text { /heat-sensitive thermal } \\
\text { imaging, signal, security } \\
\text { cameras \& night animal } \\
\text { research, TV remotes, } \\
\text { DVD players projectors } \\
\text { fiber optic cables, internet } \\
\text { connections http://en .into } \\
\text { xication-stop.com/infra } \\
\text { krasnoe-izluchenie-vliy } \\
\text { anie-na-cheloveka_html } \\
\text { default.htm }\end{array}$ \\
\hline & FIR & $\begin{array}{l}0.900 \\
1.0 \mathrm{~nm} \quad(\quad \\
\text { months })\end{array}$ & $\begin{array}{l}3-100 \\
\mu \mathrm{m})\end{array}$ & & $\begin{array}{ll}\text { mild } & \text { transient } \\
\text { erythema } & \end{array}$ & $\begin{array}{l}\text { Treating facial wrinkles } \\
\text { \&hyper pigmented lesions } \\
\text { Lee J. H. et al., }(2006)^{[3]}\end{array}$ \\
\hline
\end{tabular}

NB: UV: Ultraviolet, IR: Infrared PPE: protect skin and eyes 
2. Cities and Industrial areas are excess lighted by light pollution put to human and animal's health at risk by deviation to their circadian rhythm, nocturnal activities of the livings.

3. Millions of birds were killed annually due to LP as they miss their migration route and time table, nest building schedule. Millions of birds die due to collision in light post and buildings. Light pollution distracts many species both marine and inland.

4. Excess artificial light can disrupt the seasonal cycle of flowering, fruiting and yield of the plant kingdom known as SAD (Seasonally affective disorder) of plants. Since the radiance and light pollution is increasing regularly, the annual yield shall decrease whereas the population is rising exponentially shall invite mass extinction.

5. It is estimated that the outdoor and parking places lighting consume enormous ( $\approx 120$ terawatt hours only) in US whose $50 \%$ is unnecessary and unproductive which consumes 21MMT of Carbon https://astronomers with outborders.org/gam2015-programs/dark-skies-awareness/dsa-blog/2634-5-appalling-facts-about-light-pollution.

6. Major portion of global species are living under LP. So light pollution is a universal concern. The night sky in urban or suburban is under glare or over illumination. According to World Atlas of Artificial Night Sky Brightness in 2016 study, $80 \%$ of the world's population lives under sky glow.

7. Artificial lights overweigh the darkness of our urban areas and disrupt the natural day-night pattern and deteriorate the delicate balance of our ecosystem and environment.

8. The most notable impact of light pollution is wastage of electricity or energy. Light pollution induces the air pollution. More use of electric energy harnesses more thermal power plants and more use of fossil fuel and accelerates air pollution.

9. Excessive lighting in outdoor areas can cause a lot of glare and can impact visibility of drivers and pedestrians.

10. Compact fluorescent lamps (CFL) and Light emitting Diode (LED) bulbs emit blue light wavelength that scatters easily into the atmosphere, which causes eyestrain, impairs night vision and adds to light pollution.

11. Excessive lighting causes sleep disorder and many other health risks such as obesity, depression, diabetes, breast cancer and blistering and many more.

12. It must be understood that white light sources, such as metal halides, CFLs or LEDs, must be used with precaution. These lights emit high levels of bluish light that interferes in risk of vision and health. Whereas incandescent or high pressure sodium vapor lamps, produces high levels of reddish or even infrared light.

\section{Effect on Faunal diversity:- \\ Effect on animals:}

Light affects the growth, coloration of body/feathers, migration, reproduction and diapause of various animals (reptiles and mammals), birds, fishes, insects etc. Some faunae favor darkness and others only survive in light. Metabolism of plants are controlled by light through its pigment system (chlorophyll and photochromic) whereas in animals by the photo receptors and visual organs. The light has effects on the protoplasm, metabolism, pigmentation, movement, phototropism, use of biological clock for their celestial orientation, Photoperiodic (Circadian and circa annual rhythms), reproduction, development and biological rhythm (lunar or semilunar periodicity) of animals,

If excess of harmful artificial light intervene in the life system of these animals on long term basis, their photoperiodic or biological rhythms shall disrupt. The reproduction, development shall slow down under the ill effects of LP. Apprehending vulnerability to their life the fauna shall migrate to the place where he will not be endangered. If unable to migrate, the endangered species shall lead towards extinction. In India the vultures, foxes, jackals, elephants and rhinos and many animals have become endangered either due to loss of habitation or LP.

Predators hunt in light by using darkness as cover. But in urban and its fringes have no discrimination of night and day due to light pollution. Birds cannot sleep at night and few cave living animals could not discriminate between day and night. Glare from township have disturbed the circadian life style of aqua habitat species. Sea turtles lay eggs in coasts. The hatchlings enter the sea in the direction of horizon glare. But light pollution is misdirecting large numbers of them in opposite direction and finally the baby turtles fall prey to death.

The chrono biotic hormonal regulator, the Melatonin is essential for the neoplastic cell growth of Homosapiens and of all animals. Dusk is the alarm for the hormonal signal of our biological clock. Night tells animals to decide its times of eating, sleeping, hunting, reproduction and migration activities. 


\section{Effect on Avifauna:}

The exuberant light and over illumination can upset the path and flight patterns of arctic birds. Artificial light can attract and disorient nocturnal birds causing delay in their movement and reaching the destination. Nocturnal migratory birds use the moon and stars for their voyage along the artic or subarctic paths during their bi-annual migrations. Birds living in urban are also getting sleepless nights due to artificial bright lights and insect eater birds have developed aberrant activities at night. Light pollution invites some birds/insects to succumb to deadly collisions with buildings/light posts and other objects due to excitation by developing apparent blindness. Photo taxis properties are exhibited by some insects and birds. Navigator migrant animals, birds and insect's exhibit innate behavior of kinesis, taxis and reflex action as key stimulus but the Anthropocene nocturnal light pollution add to the problem by distracting and disorienting their locomotion. Their genetically controlled behavior have changed under influence of light pollution (http://www.yourarticlelibrary.com/environment/what-are-the-major-effects-of-light-onanimals-7-effects/3799)

\section{Faunal diversity (VIVO):}

It has been observed by Posch et al $(2003)^{[25]}$ that the illuminaces of normal clear sky $(\approx 20-30$ millilux $)$, but a cloudy sky can go up to $\approx 550$ millilux. Similarly the illuminaces increases as night proceeds and before midnight it is the highest $(\approx 120$ millilux $)$. The luminance of some light sources like integrated star-moon night, $\left(80-85 \mu \mathrm{cd} / \mathrm{m}^{2}, \approx 0.260\right.$ millilux), Dark sky $\left(160-180 \mu \mathrm{cd} / \mathrm{m} 2, \approx 0.530\right.$ millilux), Milk-way $\left(3.700 \mu \mathrm{cd} / \mathrm{m}^{2}\right.$ at NBG=15, $\approx 11.6 \mathrm{millilux}$ and human eye rods sensitivity $\left(4.700 \mu \mathrm{cd} / \mathrm{m}^{2}\right.$ at $\left.19 * \mathrm{NBG}, 14.8 \mathrm{millilux}\right)$ respectively. These limits of luminance adaptation by the cones of human eye are 5millilux. The adaptation of human eye commences from 30 millilux and goes down to $10^{-6} \mathrm{Lux}$ or $1 \mu \mathrm{cd} / \mathrm{m}^{2}$. The illuminaces of a window during full moon is $300 \mathrm{milliflux}$ whereas halfmoon luminance is 30millilux of the same window under similar conditions. But the harmful blue light has wavelength of $\approx 420 \mathrm{~nm}$.

\section{LP and Human eye (Vitro):-}

Effect on protoplasm: The skin and hair on the body saves the animal/aqua fauna kingdom from toxic effect of solar radiation. The nocturnal light pollution distract the radiation and causes excitation, activation, sleepless, affect the protoplasm and UV changes mutational processes of some organs.

Effect on metabolism: The behavioral changes in animals have been marked due to LP like higher enzyme activity, low metabolic growth, increased sluggishness and high solubility of gasses, salts and minerals in the protoplasm. Habitats alternate their day life style as sleeping time and night for quest for food. The artificial light (Specially LED) with specific intensity and wavelength can deploy the vegetal metabolism so as to rise in yield of plants and functionalized foods to the growing population Darko et al., (2014) ${ }^{[26]}$. Photo synthesis, activities apportioning between day and night (dusk and dawn)and dark repair and recovery (DNA by UVA) of some species gets distorted due to light pollution by artificial illumination.

Effect on pigmentation: LP enhances light exposure time that upset pigmentation of the body of the animals which changes in their protective coloration and sexual dimorphism. The photo taxis properties controls pigmentation of animals and colour of feathers of birds. The +ve photo tactic livings have a deep black coloration whereas - ve animals/aqua habitats are white in complexion.

Visual perception: Many species are affected by the sky glow effects of LP (when glaze is higher than full moonlight) create visual confusion (between dawn and dusk) and extend effective span of day activities. The visual perception of some birds and animals force them to change their place of habitation on availability of sufficient food. The visual perceptions of some migratory Siberian birds have compelled them to stay permanently around sanctuaries of India and have their daily activity throughout night (e.g. wading birds).

\section{Faunal diversity (Vitro)}

Effect on daily locomotion: The attractive or repulsive locomotion of some photo tactic animals have influence on their photo taxis property and life style. The positive photo tactic property possessing animals and aqua habitats are some fish species, birds attracted towards artificial light (bats, Owl, cricket, sea birds) and animals are lions, hyena, leopards, black rhinos, honey badger, red fox and many others only prey during night. Artificial illumination bleaches the visual pigments of migratory birds by distracting them by sight of horizon Claudia Rieswijk., (2014) ${ }^{\text {[27] }}$ 


\section{Effect of Celestial orientation}

Some arthropods, marine snails, animals, avifauna and aqua fauna use their time sagacity (biological clock and observations on azimuthal positioning) to decide their path by using the sun, moon, or stars as path finder (compass). The species use celestial orientation for their migration, breeding and food/nest search. Some aqua habitats like fishes, crabs, snails and turtles, some snakes, lizards, ants, bees and some birds and invertebrates such as, wolf, jackal, spiders and sand hoppers, lions, polar bears etc. use celestial orientation for their life style..

Circadian cycles and photoperiodism: Most of the taxa's and many plants are likely to be affected LP and disrupt circadian clocks and photoperiodism. Plants and Taxes are also affected by the blue light through the crypto chrome pathway Song Y. H. (2010) ${ }^{[28]}$. The orbital/seasonal and the annual rotation of earth along with global obliquity regulate daily activities, behavior, re-productivity; migration adjusts their adaptation to morphology, physiology and ecology of terrestrial, amphibians and aquatic species. The circadian rhythms like day and night, daily pattern of leaf and flower movement are regulated by sun, moon and seasonal environmental thrust. But light pollution left less discrepancy between span of day and night and has disrupted the free running of life style of all living being. Photo planktons in Himalayan lakes (Kashmir lake) moves 2 to 2.5 m underwater as diurnal variation Kant and Kachroo, $(1975)^{[29]}$.

Effect on reproduction: Some species have essentially need light which is necessary for the activation of annual reproduction and breeding activities. The light pollution with prolonged illumination increases the sexual activities in many species and increases their population and some have vice versa. Some birds and insects are largely affected in urban areas due to excess artificial illumination. Frogs stopped singing before their mating, Similarly some Olive Rudely turtles, prawns and crabs enter the Chilika Lake flying or swimming for thousand kilometers along the Arctic way or through sea to breed. When breeding season is over they fly back in same path or swim away to deep sea of Bay of Bengal.

\section{Spatial orientation and light environment:}

Some species are highly sensitive to directional light. Isolated light sources like lights from light houses, ships and launches have disruptive effect on their navigation. Excess illumination, glare and clutter cover the nadir horizon and mask natural light signals used for navigation of birds, animals. Also the masking of lunar cycle interrupts living activities of many species. Jackals stopped howling in semi-urban areas, elephants entering urban areas causing destruction being disillusioned by light pollution.

\section{Reducing Light pollution:}

Impacts on the potential health all living's is triggered by artificial light though the probability is low.at present. Electric illumination started from 1879, after Thomas Elva Edison. In $21^{\text {st }}$ century, stars have become invisible in most of the cities with missing night span due to urban sky glow. Light is necessary to increases the length of productive day, offering recreational activities but present artificial alfresco lighting has been made of excess illumination, irritating and redundant. Such unnecessary light is fastest growing, most pervasive and considered as pollution. Doctors claim exposure of retina to photons causes disruption in circadian rhythm like sleep, reproductive activities. The artificial night sky brightness has been exceeded the threshold light by more than $10 \%$ in developing and developed countries and continuously rising. It is high time to think of it and impart appropriate steps. Some of the steps to be taken are:

1. Turn it off: Fighting against light pollution is not to turn off all light sources. Light pollution only can be ameliorated by protecting detrimental light sources such as use of radio lights, X-rays and LASER lights which are injurious to vision. Monochromatic Light should be used for minimum illumination. Use of fluorescent lamps, LED's, sodium lights and HFL to be limited by law and its fruitful implementation. Fighting light pollution is only lighting those areas which needs to be illuminated. Shade on a lamp is the best practices.

2. Avoid UV and blue light exposure: Result of UV can be abridged by evading noontime sun, wear tight white clothing that block sunrays, use sunglasses and hat that can shade face, neck, eye and ears. Apply sunscreen of SPF of 30 or higher to all sun exposed skin. Shield the lights so lights shine down and not up, use timers, dimmers and motion detectors..

3. Shielding: Use only the indispensable quantity of illumination and switch off redundant lighting (decorative flood lights, Fluorescent lights for advertising in late night till next day evening. Shield the light, with a solid cap above the bulb that avoids light being exposed directly upward.

4. Sensor outdoor lights: Shield of exiting fixtures, and its marketing and installation to be standardized. Motion sensors are to be installed street/lawn lights. Test/ adjust the signal/motion detector's sensitivity depending upon its necessity. 
5. Public awareness: Train family members/neighbors about healthy lighting system particularly about blue light at night. Check LP by blog posts, use light only when needed, install light timers, shield all alfresco lights, less movement at night.

6. Appropriate source: LED's are brighter, energy efficient (135 lumens/watt), long life ( $\approx 50,000$ hours), rugged (called "Solid State Lighting (SSL)), instant glow, weather proof, directional, excellent color rendering, Environment friendly and easily control brightness and color. So LED lights can be a tool for Light pollution but possess less illumination.

7. Cut Off: Outdoor lights with adequate cut off angles do not go up to pollute sky. It may be full cut off, cut off, semi cut off or Non-cut off as per The Illuminating Engineering Society of North America (IESNA). Imposing quality exterior illumination one should cut electrical energy utilization by 60 to $70 \%$ and simultaneously save energy.

Table 7:- $\quad$ Cut Off of Outdoor lights with adequate cut off angles as per The Illuminating Engineering Society of North America (IESNA)

\begin{tabular}{|c|c|c|c|c|}
\hline \# & Cut off Type & $\begin{array}{l}\text { Illumination }(\mathrm{Cd} / 1000 \\
\text { lamp Lumens) / should } \\
\text { not exceed } \%\end{array}$ & $\begin{array}{l}\text { Vertical Angle } \\
\text { in deg. from } \\
\text { nadir }\end{array}$ & Remarks \\
\hline 1 & Full cut off & $100 \mathrm{Cd} / 10 \%$ & $80^{\circ}$ & $\begin{array}{l}\text { No light is distributed at or above an angle of } 90^{\circ} \\
\text { from the nadir along all lateral angles around the } \\
\text { light source }\end{array}$ \\
\hline \multirow[t]{2}{*}{2} & \multirow[t]{2}{*}{ Cut off } & $<25 \mathrm{Cd} / 2.5 \%$ or & $90^{\circ}$ & \multirow{2}{*}{$\begin{array}{l}\text { Cutoff light fixtures allow a small amount of up } \\
\text { lighting, this applies to all lateral angles around } \\
\text { the source, }\end{array}$} \\
\hline & & $100 \mathrm{Cd} / 10 \%$ & $80^{\circ}$ & \\
\hline \multirow[t]{2}{*}{3} & \multirow[t]{2}{*}{ Semi cutoff } & $<50 \mathrm{Cd} / 5 \%$ & $90^{\circ}$ & \multirow{2}{*}{$\begin{array}{l}\text { Emit more light directly to sky Applies all lateral } \\
\text { angles around the source. }\end{array}$} \\
\hline & & $<200 \mathrm{Cd} / 20 \%$ & $80^{\circ}$ & \\
\hline 4 & Non-cutoff & No limit & & $\begin{array}{l}\text { Fixtures distribute light without Candela } \\
\text { limitation in the zone above the max Candela. }\end{array}$ \\
\hline
\end{tabular}

Select exterior light fixtures with cutoff angles to prevent light from escaping above the horizontal plane (nadir), minimize up lighting, and reduce high-angle brightness. Cutoff lighting emits illumination down to the ground where it's most needed and in many cases, improves visibility. provides the following cutoff classifications as in

Table -7

8. Legalization and certification: The International Development Association (IDA) of World Bank has been designated sky glow, landscape lights, light spill and minimize glare for various illuminating system like chandeliers, pendants, flash lights, revolving lights in circus and light houses of ports. These long wavelength lights do not scatter easily and adds to light pollution. They should be mounted at low angles to minimize light pollution. Accept membership from the International Dark-Sky Association to observe Fatal light awareness program (FLAP). The lights before use should be certified and well shielded or otherwise legal action to be imposed on the user. Invoke lighting ordinances by local and federal government to reduce light pollution.

9. Light pollution is an acute problem in the Anthropocene epoch. A sufficient knowledge gap exists about light pollution and its impact ameliorations. Since photo pollution affect the realm of living flora and fauna.

10. Cloud seeding during smog or haze artificially to spray moisture as silver iodide or dry ice in the clouds by an aircraft or high pressure gun to have a rain and clearing the haze or smog.

The slogan for minimization of detrimental effects of pollution use exterior lights when needed, required area, brightness and well shielded with quality lighting without blue light/UV emission. Install CCTV camera for watch and ward, sensor the outdoor lighting system and motion/direction sensors in automobiles

\section{The conclusion:-}

Since the creation of the livings, balance exists between day and night. Productive activities are done in day and night is for rest. This delicate balance has been shifting during Anthropocene Epoch due to increased LP. The importance of nocturnal activities of all species of the world is slowly loosing. The plants, birds, animals, aqua fauna, habitats and microorganisms including human are prey to light pollution and continuously increasing in all the countries except a few conscious countries like US, UK, Canada and Russia and many other. The areas showing the maximum effects of LP are Asia, (West Asia), Africa and South America. The rich and developing countries are approaching towards Kuznets curve of environment for outdoor light and LP. 
LP in India is continuously increasing in almost all the cities and the country is increasing @ 2.3\%/annum from 1992 whereas the six major cities have increase of @102\% in 2014 to 2017 considering 2013 is the base year. Radiance of the Chennai city is the highest followed by Mumbai and New Delhi. The artificial, the ratio of natural radiance to artificial radiance have also increased and the cities in decreasing order are Hyderabad, Calcutta and New Delhi. The Bortle scaling of the major cities of India are mostly of class 8-9. It is high time to monitor the radiance, artificial pollution and appropriate steps to ameliorate the LP by framing legislation.

\section{Acknowledgement:-}

I am obliged to Dr. Mrs. Bidyutalata Mishra and Dr. Ashok Ku. Nanda ophthalmologists who have helped while preparation of the manuscript.

\section{References:-}

1. Mishra S. P., 2017, The apocalyptic Anthropocene epoch and its management in India, Int. Jour. Adv. Research, Vol, 5(3),pp. 645-663, DOI10.21474/IJAR01/3555

2. Vatansever F. and Hamblin M. R., 2013, Far infrared radiation (FIR): its biological effects and medical applications, PMC, Photonics Lasers Med., Vol- 4:PP- 255-266,doi:10.1515/plm-2012-0034

3. Lee J. H., Roh M. R., and Lee K. H.2006, Effects of Infrared Radiation on Skin Photo-Aging and Pigmentation, Yonsei Med J., Vol- 47(4), pp- 485-490, doi: 10.3349/ymj.2006.47.4.485, PMCID: PMC2687728

4. Wäldchen S., Lehmann J., Klein T., Linde S. van de, \& Sauer M., 2015, Light-induced cell damage in livecell super-resolution microscopy, Scientific Reports, vol. 5, Article number: 15348 , doi:10.1038/srep15348

5. Youssef P. N., Sheibani N. and Albert D. M., 2010, Retinal light toxicity, Eye (Lond). Vol- 25(1): pp-1-14, doi: 10.1038/eye.2010.149

6. Ron Chepesiuk, 2009, Missing the Dark: Health Effects of Light Pollution, Environ Health Prospect, Vol 117(1): pp- A20-A27, PMC2627884

7. Cho S., Shin M. H., Kim Y. K., Seo E., Lee Y. M., Park C. H., Chung J. H., 2009, Effects of Infrared Radiation and Heat on Human Skin Aging in vivo, Elsevier, Journal of Investigative Dermatology Symposium Proceedings, Vol- 14 (1), Pp- 15-19, https://doi.org /10.1038/jidsy mp.2009.7

8. Slama R. B., 2016, Green House Effect vs. Infrared Radiation Emissions. J Climatol Weather Forecasting 4:161. doi:10.4172/2332-2594.1000161

9. Falchi F., Cinzano P., Duriscoe D., Kyba C. C. M., Elvidge C. D., Baugh K., Boris et al., 2016, The new world atlas of artificial night sky brightness, Science Advances 10 Jun 2016, Vol. 2 (6), DOI: 10.1126/sciadv.1600377, http://advances.sciencemag.org/content/2/6/e1600377.full

10. Zhang Q., Pandey B., Seto K. C., 2016, A Robust Method to Generate a Consistent Time Series From DMSP/OLS Nighttime Light Data, IEEE Transactions on Geoscience and Remote Sensing ( Volume: 54 (10), Oct. 2016, pp- 5821-31, DOI: 10.1109/TGRS.2016.2572724

11. Gaston, K. J., Bennie, J., Davies, T. W. and Hopkins, J. (2013), The ecological impacts of night time light pollution: a mechanistic appraisal. Biol Rev, 88: 912-927. doi:10.1111/brv.12036

12. George M. P., Kaur J., B, Sharma A, Mishra S., 2013, Delhi Smog 2012: Cause and Concerns. J Pollut Eff Cont 1:103 doi: 10.4172/2375-4397.1000103

13. Kyba C. C. M., Kuester T., de Miguel A. S., Baugh K., Jechow A., et al., 2017, Artificially lit surface of Earth at night increasing in radiance and extent, Science Advances, Vol. 3 (11), e1701528, DOI: 10.1126/sciadv. 1701528

14. Bortle J. E., 2006, Gauging Light Pollution: The Bortle Dark-Sky Scale, Sky and Telescope, http:// www.skyandtelescope.com/astronomy-resources/light-pollution-and-astronomy-the-bortle-dark-sky-scale/

15. British Standards Institute, 2003, Road lighting part 2: performance requirements, BS EN13201-2:2003, London.

16. Gaston K. J., J. Bennie, Davies T. W., Hopkins J., 2013, The ecological impacts of nighttime light pollution: a mechanistic appraisal, Cambridge Philosophical Society, Volume 88 (4), November 2013 ,Pages 912-927, DOI: $10.1111 /$ brv.12036

17. Hunter P., 2007, The human impact on biological diversity, How species adapt to urban challenges sheds light on evolution and provides clues about conservation, EMBO Rep. 2007 Apr; 8(4): 316-318. doi: 10.1038/sj.embor.7400951PMCID: PMC1852758Science and Society Analysis. 
18. Lamar H. A. S., Kocifaj M., 2013, Light Pollution in Ultraviolet and Visible Spectrum: Effect on Different Visual Perceptions, PLoS One. 2013; 8(2): e56563, Published online 2013 Feb 18. doi: 10.1371/journal.pone.0056563.

19. Bhandari L. and Roychowdhury K., 2011, Night Lights and Economic Activity in India: A study using DMSPOLS night time images, Proceedings of the Asia-Pacific Advanced Network 2011 v. 32, p. 218-236, http://dx.doi.org/10.7125/APAN.32.24, ISSN 2227-3026

20. Waters C. N., Wagreich M., Zalasiewicz J., and the Anthropocene Working Group, 2018, Global Boundary Stratotype Section and Point (GSSP) for the Anthropocene Series: Where and how to look for potential candidates, Geophysical Research Abstracts Vol. 20, EGU2018-4590, 2018EGU General Assembly, Conference: European Geosciences Union, General Assembly, Feb 2018, At: Vienna 2018

21. Garstang R. H., 1986, Model for artificial night-sky illumination, the Astronomical Society of the Pacific, Vol. 98, NO.601/MAR, P. 364, 1986PASP...98..364G

22. Cinzani P., 2004. A portable spectrophotometer for light pollution measurements, Memor. Soc. Astrom. Ital. Supplement 5, 395.

23. Cinzano P, and Elvidge C. D., 2004, Night sky brightness at sites from DMSP-OLS satellite measurements, Mon. Not. R. Aston. Soc. Vol- 353, pp- 1107-1116, doi:10.1111/j.1365-2966.2004.08132x.

24. World Atlas 2015 data credits: Falchion, Fabio; Ciano, Pier Antonio; Durance, Dan; Kyla, Christopher C. M.; Elide, Christopher D.; Baugh, Kimberly; Porto, Boris; Rybnik ova, Natalia A.; Forgone, Riccardo (2016): Supplement to: The New World Atlas of Artificial Night Sky Brightness. GFZ Data Services. http://doi.org/10.5880/GFZ.1.4.2016.001

25. Posch Th., Hollan J., Kerschbaum F. and Bleha M., 2003, Artificial Sky Brightness and Human Vision, http://amper.ped.muni.cz/noc/english/canc_rhythm/PV_measur_Posch.pdf

26. Darko Eva, Heydarizadeh P., Schoefs B., Mohammad R. S., 2014, Photosynthesis under artificial light: the shift in primary and secondary metabolism, Philosophical transactions, R Soc Lond B Biol Sci. ,Vol- 369(1640): 20130243. doi: 10.1098/rstb.2013.0243, PMCID: PMC3949401

27. Rieswijk Claudia, 2014, Insects, bats and artificial light at night, Measures to reduce the negative effects of light pollution, Master's Thesis, Ecology \& Natural Resource Management, University of Utrecht, pp- 1-55

28. Song Y. H., Shogo Ito and Imaizumi T.,2010, Similarities in the circadian clock and photoperiodism in plants, Curr Opin Plant Biol. Vol- 13(5), pp-594-603, doi: 10.1016/j.pbi.2010.05.004

29. Kant S., Kachroo P., 1975, Limnological studies in Kashmir lakes II, Diurnal Movement of Phytoplankton, Jour. Of Indian Botanical Society, Vol 54 (1/2), pp 9-12 